\title{
Anti-IgLON5 Disease
}

\section{A New Bulbar-Onset Motor Neuron Mimic Syndrome}

\author{
Jana Werner, MD, Ilijas Jelcic, MD, Esther Irene Schwarz, MD, Elisabeth Probst-Müller, MD, PhD, \\ Jakob Nilsson, MD, PhD, Bernhard Schwizer, MD, Konrad Ernst Bloch, MD, Andreas Lutterotti, MD, \\ Hans-Heinrich Jung, MD,* and Bettina Schreiner, MD*
}

Correspondence

Dr. Schreiner

bettina.schreiner@usz.ch

Neurol Neuroimmunol Neuroinflamm 2021;8:e962. doi:10.1212/NXI.0000000000000962

\section{Abstract}

\section{Objective}

To expand the spectrum of anti-IgLON5 disease by adding 5 novel anti-IgLON5-seropositive cases with bulbar motor neuron disease-like phenotype.

\section{Methods}

We characterized the clinical course, brain MRI and laboratory findings, and therapy response in these 5 patients.

\section{Results}

Patients were severely affected by bulbar impairment and its respiratory consequences. Sleeprelated breathing disorders and parasomnias were common. All patients showed clinical or electrophysiologic signs of motor neuron disease without fulfilling the diagnostic criteria for amyotrophic lateral sclerosis. One patient regained autonomy in swallowing and eating, possibly related to immunotherapy.

\section{Conclusion}

IgLON5 disease is an important differential diagnosis to evaluate in patients with bulbar motor neuron disease-like phenotype and sleep disorders. There is need for a deeper understanding of the underlying pathobiology to determine whether IgLON5 disease is an immunotherapyresponsive condition.

\footnotetext{
*These authors contributed equally to this work..

From the Department of Neurology (J.W., I.J., A.L., H.-H.J.), Department of Respiratory Medicine and Sleep Disorders Center (E.I.S., K.E.B.), Department of Immunology (E.P.-M., J.N.), University Hospital Zurich; Lindenhofspital (B. Schwizer), Bern; and Department of Neurology and University Zurich Institute of Experimental Immunology (B. Schreiner), University Hospital Zurich, Switzerland.

Go to Neurology.org/NN for full disclosures. Funding information is provided at the end of the article.

The Article Processing Charge was funded by University Hospital Zurich.

This is an open access article distributed under the terms of the Creative Commons Attribution-NonCommercial-NoDerivatives License 4.0 (CC BY-NC-ND), which permits downloading and sharing the work provided it is properly cited. The work cannot be changed in any way or used commercially without permission from the journal.
} 


\section{Glossary}

AHI = apnea-hypopnoea-index; ALS = amyotrophic lateral sclerosis; ASV = adaptive servo-ventilation; CPAP = continuous positive airway pressure; FOIS = Functional Oral Intake Scale; OSA = obstructive sleep apnea; PEG = percutaneous endoscopic gastrostomy; PSG = polysomnography.

Patients presenting with sleep apnea, REM-sleep behavior disorder or non-REM parasomnia, and stridor who are seropositive for anti-IgLON5 antibodies have been first described in $2014 .{ }^{1}$ Since then, more than 60 cases with anti-IgLON5 disease have been reported. ${ }^{2,3}$ The function of the IgLON5 protein, a neuronal cell adhesion molecule, and the pathomechanism of antiIgLON5 antibody-associated diseases are still insufficiently understood. Neuropathologic postmortem findings of a few cases include gliosis, neuronal loss, and neuronal agglomeration of hyperphosphorylated tau protein in areas correlating with the clinical deficits such as signs of dysfunction of the brainstem, tegmentum, hypothalamus and hippocampus areas, and to a lesser extent, anterior horns of the spinal cord. ${ }^{4}$

Whether anti-IgLON5 antibodies directly cause neuronal dysfunction and degeneration ${ }^{5}$ or only are produced secondary to a neurodegenerative process is unclear. The strong association with HLA-DRB1 ${ }^{*} 10: 01$ and HLA-DQB1 ${ }^{*} 05: 01$ alleles suggests an autoimmune pathogenesis. ${ }^{1,2}$ Among anti-IgLON5 antibodies, the noncomplement-fixing IgG4 subclass predominates over IgG1, but the latter can induce internalization of IgLON5 in vitro. ${ }^{5}$ Previous case reports described patients with (1) sleep behavior abnormalities, (2) a progressive supranuclear palsy-like phenotype, (3) a bulbar syndrome, ${ }^{6,7}$ and (4) cognitive decline with or without chorea. ${ }^{2,3}$ In addition, Wenninger, Honorat, and colleagues reported the presence of motor-neuron signs (e.g., fasciculations, atrophy, and spasticity) in some patients with antiIgLON5 disease. ${ }^{8,9}$ Bulbar symptoms combined with these signs can led to suspect a bulbar-onset motor-neuron disease. Here, we present 5 anti-IgLON5-seropositive patients with predominant bulbar dysfunction including severe laryngeal stridor causing episodes of respiratory failure, different types of sleep-related breathing disorders, and parasomnia and dysphagia that received immunotherapy and partially improved or stabilized during the disease course. Patients with IgLON5-associated disease were identified by the clinical phenotype and polysomnography (PSG) findings. They were referred to the Neuromuscular Center, University Hospital Zurich, Switzerland, between August 2017 and November 2019 for bulbar symptoms and with the question whether there were further signs of motor neuron disease. This observational study should alert physicians to consider anti-IgLON5 disease as differential diagnosis of a clinical phenotype resembling bulbar-onset motor neuron disease.

\section{Methods}

\section{Patient Consents}

Informed consent was obtained from all 5 patients in this clinical case series.

\section{Data Availability}

Anonymized data including laboratory results, imaging, and electrophysiologic and sleep testing data will be shared by request from any qualified investigator.

\section{Case Descriptions}

\section{Clinical Findings}

Five men aged 52-77 years (median: 70) at diagnosis presenting with recurrent respiratory distress and progressive neurogenic dysphagia as cardinal symptoms were referred because of suspicion of bulbar-onset motor neuron disease. The time from onset of symptoms to diagnosis of antiIgLON5 disease ranged from 7 months to 3.5 years (median 2 years). None of them had a history of autoimmune disease or cancer. The demographics and clinical features are described in detail in tables 1 and 2. Two patients (patients 1 and 3) presented with recurrent acute hypercapnic respiratory failure because of laryngeal dysfunction requiring intubation and subsequent tracheotomy: Patient 1 had been diagnosed with obstructive and central sleep apnea 3 years earlier, but both continuous positive airway pressure (CPAP) and adaptive servoventilation (ASV) were unsuccessful. Episodes of acute dyspnea accompanied by stridor worsened and led to repeated tracheal intubations. Furthermore, he developed dysarthria and dysphagia over the previous 2 years. Patient 3 had a 9-month history of severe dyspnea attacks resulting in acute hypercapnic respiratory failure that were also attributed to laryngeal dysfunction. Three patients were referred mainly because of progressive dysphagia with weight loss, tongue dysmotility, and dysarthria for 7 months (patient 5) to 1.5-2.5 years (patient 4 and 2). In addition, patients 2 and 4 complained of episodes of breathing difficulties and disturbed sleep with daytime sleepiness (patient 2) or recurrent nocturnal tongue biting (patient 4). Patients $1,2,4$, and 5 received nocturnal positive airway pressure therapy (CPAP, ASV, or bilevel positive airway pressure) 4-10 years before the diagnosis of anti-IgLON 5 disease. In patients 1, 2, 4, and 5 , clinical features of motor neuron involvement were documented including an increased jaw jerk reflex and muscle spasticity and occasional muscle fasciculations in tongue, arm and thigh muscles, facial myokymia, and cramps.

\section{Investigations}

All 5 patients had serum antibodies against IgLON5 (table 1), 2 also in the CSF. The serum anti-IgLON5 antibodies belonged to the IgG1 (patients 2-5) and IgG4 isotype (all 5 patients). By contrast, when we retrospectively tested archived serum and CSF samples of 5 male patients diagnosed 
Table 1 Demographics, Initial Findings, HLA-Alleles, Serology, and Immunotherapy

\begin{tabular}{|c|c|c|c|c|c|}
\hline & Case 1 & Case 2 & Case 3 & Case 4 & Case 5 \\
\hline \multicolumn{6}{|l|}{ Demographics } \\
\hline Age at diagnosis & 74 years & 52 years & 77 years & 63 years & 70 years \\
\hline Gender & Male & Male & Male & Male & Male \\
\hline Origin & Swiss & Sri Lankan & Swiss & Swiss & Italian \\
\hline $\begin{array}{l}\text { Time from onset to } \\
\text { diagnosis }\end{array}$ & $\begin{array}{l}\text { Approx. } 2 \text { years after } \\
\text { onset of dysarthria and } 6 \\
\text { months after onset of } \\
\text { acute respiratory crises }\end{array}$ & $\begin{array}{l}\text { Approx. } 3.5 \text { years } \\
\text { after onset of } \\
\text { dysphagia }\end{array}$ & $\begin{array}{l}\text { Approx. } 2 \text { years after } \\
\text { onset of hoarseness and } \\
14 \text { months after onset of } \\
\text { attacks of dyspnea }\end{array}$ & $\begin{array}{l}\text { Approx. } 1.5 \text { years } \\
\text { after onset of } \\
\text { dysphagia }\end{array}$ & $\begin{array}{l}\text { Approx. } 7 \text { months } \\
\text { after onset of } \\
\text { dysphagia }\end{array}$ \\
\hline Symptoms at onset & OSA & Dysphagia & Hoarseness & $\begin{array}{l}\text { Episodes of dyspnea, } \\
\text { OSA + parasomnia }\end{array}$ & OSA \\
\hline $\begin{array}{l}\text { Symptoms at } \\
\text { diagnosis }\end{array}$ & $\begin{array}{l}\text { Same as above }+ \\
\text { dysphagia dysarthria, } \\
\text { stridor and episodes of } \\
\text { dyspnea }\end{array}$ & $\begin{array}{l}\text { Same as above + } \\
\text { dysarthria, OSA, } \\
\text { increased daytime } \\
\text { sleepiness }\end{array}$ & $\begin{array}{l}\text { Same as above + } \\
\text { episodes of dyspnea, } \\
\text { dysphagia }\end{array}$ & $\begin{array}{l}\text { Same as above + } \\
\text { dysphagia }\end{array}$ & $\begin{array}{l}\text { Same as above + } \\
\text { "swollen tongue," } \\
\text { dysphagia, } \\
\text { dysarthria, and } \\
\text { dysgeusia }\end{array}$ \\
\hline $\begin{array}{l}\text { Reason for referral } \\
\text { to neurologist }\end{array}$ & $\begin{array}{l}\text { Unclear bulbar } \\
\text { symptoms }\end{array}$ & $\begin{array}{l}\text { Progressive } \\
\text { dysphagia }\end{array}$ & $\begin{array}{l}\text { Unclear difficulties with } \\
\text { voice and swallowing }\end{array}$ & $\begin{array}{l}\text { Progressive } \\
\text { dysphagia }\end{array}$ & $\begin{array}{l}\text { Progressive } \\
\text { dysphagia }\end{array}$ \\
\hline \multicolumn{6}{|l|}{ HLA-allele } \\
\hline HLA-DRB1*10:01 & $-1-$ & $+/-$ & $-1-$ & $+/-$ & $+/-$ \\
\hline -HLA-DQB1*05:01 & $+/-$ & $+/-$ & $-1-$ & $+/-$ & $+/-$ \\
\hline \multicolumn{6}{|l|}{ Anti-IgLON5 } \\
\hline In serum & Positive $(1: 1,000)^{a}$ & Positive $(>1: 1,000)^{a}$ & Positive $^{\mathrm{b}}$ & Positive $(>1: 1,000)^{a}$ & $\begin{array}{l}\text { Positive }(1: 320 \text { and } \\
1: 1,000)^{\mathrm{a}}\end{array}$ \\
\hline In CSF & Negative $^{a}$ & Positive $(>1: 100)^{a}$ & Not analyzed & Positive $(1: 32)^{a}$ & Negative $^{a}$ \\
\hline $\operatorname{IgG} 1^{c}$ & Negative & Positive & Positive & Positive & Positive \\
\hline $\operatorname{lgG} 4^{c}$ & Positive & Positive & Positive & Positive & Positive \\
\hline \multicolumn{6}{|l|}{ Immunotherapy } \\
\hline $\begin{array}{l}\text { Period between } \\
\text { onset of } \\
\text { symptoms and } \\
\text { beginning of } \\
\text { immunotherapy }\end{array}$ & $\begin{array}{l}7 \text { months after onset of } \\
\text { episodes of acute } \\
\text { dyspnea }\end{array}$ & $\begin{array}{l}\text { Approx. } 45 \text { months } \\
\text { after onset of } \\
\text { dysphagia }\end{array}$ & $\begin{array}{l}15 \text { months after onset of } \\
\text { attacks of dyspnea }\end{array}$ & $\begin{array}{l}\text { Approx. } 20 \text { months } \\
\text { after onset of } \\
\text { dysphagia }\end{array}$ & $\begin{array}{l}\text { Approx. } 7 \text { months } \\
\text { after onset of } \\
\text { dysphagia }\end{array}$ \\
\hline $\begin{array}{l}\text { Compound, } \\
\text { duration, dose }\end{array}$ & $\begin{array}{l}\text { Mercaptopurine } \\
(75 \mathrm{mg} / \mathrm{d})\end{array}$ & $\begin{array}{l}\text { IV methyl- } \\
\text { prednisolone } 1 \mathrm{~g} / \mathrm{d}, 5 \\
\text { consecutive days } \\
\text { PEX, } 5 \text { cycles, every } \\
\text { other day } \\
\text { Rituximab ( } 375 \mathrm{mg} / \\
\text { m2 body surface, } 1 \times \text { ) }\end{array}$ & $\begin{array}{l}\text { PEX, } 3 \text { cycles, every } \\
\text { other day } \\
\text { IVIG, } 2 \text { cycles }(0.4 \mathrm{~g} / \mathrm{kg} / \\
\text { d for } 5 \text { days, monthly } \\
\text { interval) } \\
\text { Rituximab }\left(375 \mathrm{mg} / \mathrm{m}^{2}\right. \\
\text { body surface, } 2 \times)\end{array}$ & $\begin{array}{l}2 \times \text { IV methyl- } \\
\text { prednisolone } 1 \mathrm{~g} / \mathrm{d}, 5 \\
\text { consecutive days } \\
2 \times \mathrm{PEX}, 5 \text { cycles, } \\
\text { every other day } \\
\text { Rituximab }(375 \mathrm{mg} / \\
\mathrm{m}^{2} \text { body surface, } 1 \times \text { ) }\end{array}$ & $\begin{array}{l}\text { IV methyl- } \\
\text { prednisolone } 1 \mathrm{~g} / \mathrm{d} \text {, } \\
5 \text { consecutive days } \\
\text { PEX, } 5 \text { cycles, every } \\
\text { other day } \\
\text { Rituximab ( } 375 \mathrm{mg} / \\
\mathrm{m}^{2} \text { body surface, } \\
1 \times \text { ) }\end{array}$ \\
\hline $\begin{array}{l}\text { Response to } \\
\text { immunotherapy }\end{array}$ & $\begin{array}{l}\text { Partial improvement } \\
\text { (PEG removed, re- } \\
\text { tracheostomy } \\
\text { necessary) }\end{array}$ & $\begin{array}{l}\text { Persistent bulbar } \\
\text { symptoms } \\
\text { (tracheostomy } \\
\text { recommended but } \\
\text { refused by patient) }\end{array}$ & $\begin{array}{l}\text { Partial improvement } \\
\text { (swallowing), } \\
\text { (tracheostomy) }\end{array}$ & $\begin{array}{l}\text { Persistent dysphagia } \\
\text { (PEG), recurrent } \\
\text { attacks of acute } \\
\text { dyspnea } \\
\text { (tracheostomy) }\end{array}$ & $\begin{array}{l}\text { Persistent } \\
\text { dysphagia, (PEG } \\
\text { and tracheostomy) }\end{array}$ \\
\hline mRS at last visit & 2 & 2 & 2 & 3 & 3 \\
\hline
\end{tabular}

Abbreviations: IVIG = IV immunoglobulins, mRS = modified Rankin Scale; PEG = percutaneous endoscopic gastrostomy; PEX = plasma exchange. Cell-based immunofluorescence assays performed ${ }^{a}$ at the Dep. of Clinical Immunology, University Hospital Zurich, bat the Dep. of Neurology, Medical University of Innsbruck, Austria, 'analyzed by Euroimmun, Lübeck, Germany.

previously with amyotrophic lateral sclerosis (ALS) and identified by a search in our neuromuscular center database, they were negative for anti-IgLON5 antibodies (ALS "clinically possible" or "definite" according to the Awaji criteria, ${ }^{10}$ age range: $57-75$ years; 4 with bulbar symptoms). There were no inflammatory changes in the CSF of patients 
1-5 except mild-to-moderate elevated CSF protein (no intrathecal IgG synthesis in 3 of 5 CSF samples analyzed). Brain and spinal cord MRI findings of all 5 patients were unremarkable. Serologic tests were negative for HIV, Borrelia burgdorferi, Treponema pallidum and acetylcholine receptor, muscle specific tyrosine kinase (MuSK), titin, lipoprotein receptor-related protein 4, and $\mathrm{cN}-1 \mathrm{~A}$ (Mup44) antibodies. Creatine kinase values were not significantly elevated. Analysis of phosphorylated neurofilament heavy chain (pNf-H), a proposed diagnostic biomarker for ALS, showed marginally positive results in 1 of 5 of our patient serum samples and one of one analyzed CSF samples (patient 4; analyzed by Euroimmun, Lübeck, Germany). Three of the 5 patients expressed HLA-DRB1 ${ }^{*}$ 10:01 in combination with HLA-DQB1 ${ }^{*} 05: 01$ alleles, and one patient expressed HLA-DQB1 ${ }^{*} 05: 01$ without HLA-DRB1 ${ }^{*} 10: 01$. Of the 2 patients negative for HLADRB1 $1^{*} 10: 01$, patient 3 was homozygous for HLA-DRB $1^{*} 03$ : 01 and patient 1 was HLA-DRB1 ${ }^{*} 01: 01$ and HLA-DRB $1^{*} 04$ : 04. EMG revealed subtle pathologic spontaneous activity and chronic neurogenic changes in different regions including the masseter, limb, and even thoracic paravertebral muscles in all 5 patients, individually not fulfilling the Awaji-Shima consensus criteria for $\mathrm{ALS}^{10}$ (table 2). A disturbed sleep architecture with an alpha-delta pattern was detected in the PSG of patient 1 who had a history of parasomnia (table 3). Respiratory moaning, inspiratory flow limitations with cyclic oxygen desaturations, and central apneas (apnea-hypopnea index $[\mathrm{AHI}] 16 / \mathrm{h}$ ), inspiratory stridor, smacking, and increased periodic limb movements were noted. The PSG of patient 2 demonstrated a markedly reduced sleep efficiency and REM sleep behavior disorder. A respiratory polygraphy with capnography off CPAP confirmed severe obstructive sleep apnea (OSA) and demonstrated episodes of sleeprelated hypoventilation and inspiratory stridor. The PSG of patient 4 revealed a markedly fragmented sleep profile with many arousals (rarely associated with periodic limb movements), REM sleep behavior disorder, but showed no residual sleep-disordered breathing or stridor on noninvasive ventilation. Patient 3`s PSG did not reveal any relevant breathing disorder or stridor but increased periodic limb movements in part associated with arousals. The PSG of patient 5 on ASV for treatment-emergent central sleep apnea demonstrated increased periodic limb movements and REM-sleep behavior disorder. A cardiorespiratory polygraphy after tracheotomy revealed mild central sleep apnea (AHI 14/h). A video fluoroscopic and endoscopic swallowing examination was performed in all 5 patients and showed signs of salivary and silent aspiration and laryngeal penetration. The lowest FOIS (Functional Oral Intake Scale) value reached was I-II (patients 1, 4, and 5) (level I: nothing by mouth and level II: tube feeding with minimal attempts of oral feeding), and thus, a percutaneous endoscopic gastrostomy (PEG) was inserted. The ability of oral intake in patient 2 and 3 were evaluated as FOIS value $\mathrm{V}$ (total oral intake of multiple consistencies requiring special preparations) or V to VI (total oral intake with no special preparation, but must avoid specific foods and liquid items), respectively. All patients underwent fiberoptic evaluation/laryngoscopy by ENT/phonation specialists demonstrating velopharyngeal insufficiency and functional laryngeal impairment (e.g., bilaterally impaired vocal cord function and paresis) (table 2).

\section{Follow-Up}

All 5 patients received immunotherapy that was started between 7-15 months after onset of recurrent respiratory failure (patients 1 and 3) and approximately 7 months to 3.5 years after gradual onset of dysphagia (patients 5, 4, and 2) (table 1). One patient improved (patient 1) under Mercaptopurine (up to $75 \mathrm{mg} / \mathrm{d}$ p.o.) as maintenance immunotherapy. Mercaptopurine was chosen based on the personal experience and preference of his treating neurologist back at home. On a follow-up visit, dysphagia was only mild, and it was planned to remove the PEG. Physical activity and exertional dyspnea improved. The tracheostoma was removed, but retracheotomy was necessary shortly after because of an acute dyspnea attack at night. Patient 2 received a steroid pulse therapy, plasma exchange, and a B cell depleting maintenance treatment with rituximab, but anti-IgLON5 antibody levels remained high. Nevertheless, he was doing well in the past 6 months. Patient 3 received plasma exchange, followed by IV immunoglobulins and rituximab. At follow-up visits, he reported improved swallowing and no further weight loss. He still has a tracheostoma, but there were no respiratory crisis and emergency admissions to the hospital since the first plasma exchange 11 months ago. Despite initiation of an IV methylprednisolone pulse therapy, patient 4 had to be hospitalized repeatedly because of acute episodes of laryngospasm and acute respiratory failure requiring intubation and additional plasmapheresis. The patient finally consented to a tracheostomy and PEG tube placement. After another IV methylprednisolone pulse and rituximab therapy, patient 4 still suffers from severe dysphagia, and recurrent attacks of acute dyspnea and serum anti-IgLON5 antibodies are still positive. Patients 5's immunotherapy was started with an IV methylprednisolone pulse, plasma exchange sessions, and continues with rituximab. So far, he is still dependent on the PEG tube.

\section{Discussion}

The initial symptoms suggested bulbar onset motor neuron disease further supported by the fact that all 5 patients demonstrated signs of spasticity, hyperreflexia, mild atrophy and limb weakness, and fasciculations of the tongue and peripheral muscles. Disease duration since diagnosis spanned from 3 to 19 months. It has been reported that IgLON cell surface proteins are expressed also outside of the CNS and that peripheral involvement in anti-IgLON5 syndromes can occur. ${ }^{2,3}$ Altogether, our patients did not fulfill diagnostic criteria for clinically definite $\mathrm{ALS}^{10}$ because there was no typical progressive spread to other body regions. ALS patients are at increased risk for sleep-related breathing disorders, particularly OSA and nocturnal hypoventilation. However, the sleep disturbances associated with anti-IgLON5 disease such as a short REM onset 
Table 2 Bulbar and Motor-Neuron Signs, EMG, and Other Neurological Features

\begin{tabular}{|c|c|c|c|c|c|}
\hline & Case 1 & Case 2 & Case 3 & Case 4 & Case 5 \\
\hline Bulbar symptoms & $\begin{array}{l}\text { Dysphagia dysarthria, } \\
\text { episodes of dyspnea }\end{array}$ & Dysphagia, dysarthria & $\begin{array}{l}\text { Hoarseness, episodes of } \\
\text { dyspnea, dysphagia }\end{array}$ & $\begin{array}{l}\text { Episodes of dyspnea, } \\
\text { dysphagia }\end{array}$ & $\begin{array}{l}\text { "Swollen } \\
\text { tongue," } \\
\text { dysphagia, } \\
\text { dysarthria }\end{array}$ \\
\hline Stridor & Yes & Yes & Yes & - & No \\
\hline $\begin{array}{l}\text { Laryngeal } \\
\text { dysfunction }\end{array}$ & $\begin{array}{l}\text { Bilateral vocal cord } \\
\text { paresis, } \\
\text { dyssynchrony, } \\
\text { paradoxical } \\
\text { movements }\end{array}$ & $\begin{array}{l}\text { Symmetric mobility of } \\
\text { vocal cords }\end{array}$ & $\begin{array}{l}\text { Severe bilateral vocal } \\
\text { cord paresis }\end{array}$ & $\begin{array}{l}\text { Bilateral vocal cord } \\
\text { paresis }\end{array}$ & $\begin{array}{l}\text { Bilateral vocal } \\
\text { cord paresis, } \\
\text { swelling of } \\
\text { arytenoid } \\
\text { mucosa }\end{array}$ \\
\hline Tracheotomy & Yes & - & Yes & Yes & Yes \\
\hline \multicolumn{6}{|l|}{ Motor signs } \\
\hline $\begin{array}{l}\text { Limbs, cranial } \\
\text { (except tongue) }\end{array}$ & $\begin{array}{l}\text { Increased masseter } \\
\text { reflex activity, leg } \\
\text { spasticity, arm and leg } \\
\text { muscles' } \\
\text { fasciculations, mild leg } \\
\text { muscles' atrophy }\end{array}$ & $\begin{array}{l}\text { Increased masseter reflex } \\
\text { activity, perioral } \\
\text { myokymia, }\end{array}$ & None & Perioral fasciculations & None \\
\hline Tongue & $\begin{array}{l}\text { Slightly reduced } \\
\text { tongue motility/ } \\
\text { strength, no atrophy } \\
\text { or fasciculations }\end{array}$ & $\begin{array}{l}\text { Reduced tongue motility/ } \\
\text { strength, no atrophy, but } \\
\text { fasciculations }\end{array}$ & None & $\begin{array}{l}\text { Slightly reduced } \\
\text { tongue motility/ } \\
\text { strength, no atrophy or } \\
\text { fasciculations }\end{array}$ & $\begin{array}{l}\text { Severe tongue } \\
\text { palsy, feeling } \\
\text { of having a a } \\
\text { "swollen } \\
\text { tongue," } \\
\text { fasciculations }\end{array}$ \\
\hline EMG study & $\begin{array}{l}\text { Fibs-sw (anterior tibial, } \\
\text { vastus lateralis), FPs } \\
\text { (biceps brachii) and } \\
\text { CRD (masseter), and } \\
\text { chronic neurogenic } \\
\text { changes }\end{array}$ & $\begin{array}{l}\text { Fibs (tongue, anterior } \\
\text { tibial), CRD, doublets (FDI), } \\
\text { and chronic neurogenic } \\
\text { changes }\end{array}$ & $\begin{array}{l}\text { Fibs-sw, CRD in limb } \\
\text { muscles, and signs of } \\
\text { chronic denervation }\end{array}$ & $\begin{array}{l}\text { A few FPs (masseter } \\
\text { and FDI), chronic } \\
\text { neurogenic changes in } \\
1 \text { muscle (FDI) }\end{array}$ & $\begin{array}{l}\text { A few FPs } \\
\text { (biceps, FDI), } \\
\text { mild chronic } \\
\text { neurogenic } \\
\text { changes (FDI) }\end{array}$ \\
\hline $\begin{array}{l}\text { Gait instability, } \\
\text { movement } \\
\text { disorder }\end{array}$ & $\begin{array}{l}\text { None (walks more } \\
\text { than } 1 \text { hour in the } \\
\text { mountains) }\end{array}$ & $\begin{array}{l}\text { Reduced endurance } \\
\text { (needs to rest every } 10 \\
\text { minutes when walking), } \\
\text { rare falls }\end{array}$ & $\begin{array}{l}\text { None; } 6 \text { minutes walking } \\
\text { test without aid: } 560 \mathrm{~m}\end{array}$ & $\begin{array}{l}\text { Slightly unsteady gait, } \\
\text { no falls, } 6 \text { minutes } \\
\text { walking test without } \\
\text { aid: } 420 \mathrm{~m}\end{array}$ & $\begin{array}{l}\text { None; } 6 \\
\text { minutes } \\
\text { walking test } \\
\text { without aid: } \\
400 \mathrm{~m}\end{array}$ \\
\hline $\begin{array}{l}\text { Cognitive } \\
\text { impairment, } \\
\text { neuropsychiatric } \\
\text { symptoms }\end{array}$ & None reported & $\begin{array}{l}\text { Fatigue, difficulties } \\
\text { concentrating, and } \\
\text { reduced drive and } \\
\text { executive functions } \\
\text { (neuropsychological } \\
\text { testing). Family reports } \\
\text { occasional memory } \\
\text { disturbances, confusion, } \\
\text { and visual hallucinations }\end{array}$ & None reported & $\begin{array}{l}\text { Recurrent depressive } \\
\text { disorder, "burnout } \\
\text { syndrome," reduced } \\
\text { impulse control and } \\
\text { semantic fluency } \\
\text { (neuropsychological } \\
\text { testing) }\end{array}$ & None reported \\
\hline Dysautonomia & $\begin{array}{l}\text { Episodes of } \\
\text { tachycardia (catheter } \\
\text { ablation for re-entrant } \\
\text { tachycardia), } \\
\text { tachyarrhythmia, } \\
\text { torsade-de-pointes, } \\
\text { AV-block 3rd degree }\end{array}$ & None reported & $\begin{array}{l}\text { Nycturia (BPH), } \\
\text { obstipation, night sweats, } \\
\text { during episodes of } \\
\text { dyspnea: Palpitations, } \\
\text { NSTEMI requiring } \\
\text { coronary artery stenting, } \\
\text { and DD Takotsubo } \\
\text { cardiomyopathy }\end{array}$ & $\begin{array}{l}\text { Signs of BPH, erectile } \\
\text { dysfunction, episodes } \\
\text { of tachycardia and } \\
\text { palpitations, } 24 \text { hours } \\
\text { ECG: normal heart } \\
\text { rhythm, } 71-149 \text { beats/ } \\
\text { min }\end{array}$ & $\begin{array}{l}\text { Hyperhidrosis, } \\
\text { no signs of } \\
\text { orthostatic } \\
\text { hypotension } \\
\text { (schellong test) }\end{array}$ \\
\hline
\end{tabular}

Abbreviations: $\mathrm{BPH}=$ benign prostatic hyperplasia; $\mathrm{BPH}=$ benign prostatic hyperplasia; $\mathrm{CRD}=$ complex repetitive discharges; $\mathrm{DD}=$ differential diagnosis; FibsSW = fibrillation and sharp waves; FPs = fasciculation potentials; FDI, first doral interosseus muscle; NSTEMI = Non-ST segment elevation myocardial infarction.

latency, a high proportion of REM sleep, and a low proportion of slow wave sleep and parasomnias including vocalizations, limb movements, and gesturing do usually not occur. Recently, patient populations with the classical tauopathy progressive supranuclear palsy or isolated OSA have been tested negative for IgLON5 autoimmunity. ${ }^{1,11,12}$ Our retrospective analysis of serum and CSF specimens of 5 additional patients with ALS identified by a search in our neuromuscular database revealed no reactivity against IgLON5 and supports results that these antibodies are highly specific. ${ }^{1}$ Previous data suggest that patients with anti-IgLON5 disease who are not treated or only treated with systemic corticosteroids have a higher mortality. ${ }^{3}$ Patients with a bulbar or motoneuron-like phenotype might have a worse response to immunotherapy, ${ }^{2,6,7}$ but case 
Table 3 Sleep Symptoms and Studies

\begin{tabular}{|c|c|c|c|c|c|}
\hline & Case 1 & Case 2 & Case 3 & Case 4 & Case 5 \\
\hline Parasomnia & NREM & RBD & No & NREM, RBD & RBD \\
\hline Sleep apnea & $\begin{array}{l}\text { OSA (first diagnosis } \\
2 \text { years before the } \\
\text { onset of bulbar } \\
\text { symptoms) }\end{array}$ & $\begin{array}{l}\text { OSA (first diagnosis } 2 \text { years } \\
\text { before, HSAT) } \\
\text { OSA \& hypoventilation (after } \\
\text { symptom onset) }\end{array}$ & No & $\begin{array}{l}\text { OSA, later } \\
\text { treatment- } \\
\text { emergent central } \\
\text { CSA }\end{array}$ & $\begin{array}{l}\text { OSA (first diagnosis } 11 \\
\text { years prior, PSG, AHI 65/h), } \\
\text { later treatment-emergent } \\
\text { CSA }\end{array}$ \\
\hline $\begin{array}{l}\text { PAP treatment } \\
\text { before the } \\
\text { diagnosis of IgLON5 } \\
\text { disease }\end{array}$ & CPAP, then ASV & CPAP, then BiPAP & No & CPAP, then BiPAP & CPAP, then ASV \\
\hline $\begin{array}{l}\text { Excessive daytime } \\
\text { sleepiness }\end{array}$ & - & Yes & - & No & No \\
\hline Sleep study I & PSG & $\mathrm{RP}$ & $\begin{array}{l}\text { PSG after } \\
\text { tracheotomy }\end{array}$ & PSG on NIV & PSG on ASV \\
\hline Sleep study II & - & PSG on BiPAP & - & - & RP after tracheotomy \\
\hline $\begin{array}{l}\text { Sleep latency } \\
\text { (min) }\end{array}$ & 2 & 58 & 8.5 & 19 & \\
\hline $\begin{array}{l}\text { Sleep } \\
\text { architecture }\end{array}$ & $\begin{array}{l}\text { Abnormal } \\
\text { structure, alpha- } \\
\text { delta-pattern }\end{array}$ & $\begin{array}{l}\text { Disturbed sleep architecture; } \\
\text { short REM latency, high } \\
\text { proportion of REM sleep, no slow } \\
\text { wave sleep, and long wake } \\
\text { phases }\end{array}$ & $\begin{array}{l}\text { Short REM } \\
\text { latency, } \\
\text { otherwise } \\
\text { normal sleep } \\
\text { architecture }\end{array}$ & $\begin{array}{l}\text { Disturbed sleep } \\
\text { architecture, short } \\
\text { REM latency, and } \\
\text { incomplete REM } \\
\text { atonia, }\end{array}$ & $\begin{array}{l}\text { Disturbed sleep } \\
\text { architecture; high } \\
\text { proportion of REM sleep, } \\
\text { no slow wave sleep, and } \\
\text { long wake phases }\end{array}$ \\
\hline $\begin{array}{l}\text { Arousal index } \\
\text { (events/hour) }\end{array}$ & - & 8 & 28.9 & 19.7 & \\
\hline PLMI (events/h) & 77.3 & 0 & 89.9 & 95.6 & 37 \\
\hline $\begin{array}{l}\text { Stridor during } \\
\text { sleep study }\end{array}$ & Yes & Yes & No & No & No \\
\hline AHI (events/hour) & 16.4 & 59,42 on NIV & 0.9 & 1.3 on NIV & 32 on ASV \\
\hline ODI (events/hr) & - & 124,36 on NIV & 0.2 & 1.1 on NIV & \\
\hline $\begin{array}{r}\text { Nocturnal } \\
\mathrm{SpO}_{2}(\%)\end{array}$ & 92 & 88,89 on NIV & 93 & 97 & 93 on ASV \\
\hline Hypoventilation & No & Yes & No & No & No \\
\hline $\begin{array}{l}\text { Summary of sleep } \\
\text { abnormalities }\end{array}$ & $\begin{array}{l}\text { Sleep apnea, } \\
\text { stridor, PLMD, } \\
\text { parasomnia, and } \\
\text { disturbed sleep } \\
\text { architecture }\end{array}$ & $\begin{array}{l}\text { OSA, sleep-hypoventilation, } \\
\text { stridor, and REM motor activity }\end{array}$ & $\begin{array}{l}\text { PLMD, } \\
\text { myoclonus }\end{array}$ & $\begin{array}{l}\text { Sleep apnea, } \\
\text { parasomnia, PLMD, } \\
\text { and REM motor } \\
\text { activity }\end{array}$ & $\begin{array}{l}\text { Sleep apnea, PLMD, and } \\
\text { REM motor activity }\end{array}$ \\
\hline
\end{tabular}

Abbreviations: $\mathrm{AHI}=$ Apnea-hypopnea-index; ASV = adaptive servo-ventilation; BiPAP = bilevel positive airway pressure ventilation; CPAP = continuous positive airway pressure; CRD: complex repetitive discharges; CSA = central sleep apnea; Fibs-sw: fibrillation and sharp waves; FDI = first dorsal interosseus muscle; FPs = fasciculation potentials; NREM = Non-rapid eye movement; ODI = oxygen desaturation-index; OSA = obstructive sleep apnea; PAP = positive airway pressure; PLMI = periodic limb movement index; PSG = polysomnography; RP = respiratory polygraphy.

numbers are too small to draw definite conclusions. Partial and transient improvements of symptoms could also be related to spontaneous fluctuations during the natural course of the illness. In our study, 2 of 5 patients (patients 1 and 3) demonstrated improved swallowing-related quality of life, weight status, and physical activity under immunotherapy, but laryngeal dysfunction was persistent and required long-term tracheostomy. Of note, patient 1 who fully recovered from dysphagia differed not only in the point of immune medication but also HLA-status (presence of HLA-DQB1 ${ }^{*} 05: 01$ without HLA-DRB1*10:01) and absence of anti-IgLON5 antibody of the IgG1 subclass. The potential impact of certain immune phenotypes is presently highly speculative but will hopefully be examined by larger, collaborative efforts in the future.

Taken together, anti-IgLON5 disease with bulbar syndrome is an uncommon but important diagnostic consideration for neurologists, ear nose throat, respiratory, and sleep specialist in cases of suspected bulbar onset ALS. Antibody testing should be considered in patients with stridor, acute dyspnea attacks due to upper airway dysfunction early during the disease course, OSA, a prominent sleep disorder and severe dysphagia even without inflammation in MRI, and CSF studies. Our case series has limitations because it is 
retrospective and involves a small number of patients. Whether early recognition and immune intervention alter disease progressions remains to be determined. Interdisciplinary management and care including otolaryngologists and pulmonologists is crucial to reduce the risk of respiratory failure or sudden death. Although new cases are emerging, additional mechanistic studies will be important to understand the immune process and pathophysiology underlying this disorder.

\section{Acknowledgment}

The authors are indebted to our patients who participated in this research. The authors would like to thank Dominik Jäger, Inga Dettmann, Swantje Mindorf, Katharina Zeplin (Euroimmun) for anti-IgLON5 IgG subclass testing, and Florian Deisenhammer (Clinical Department of Neurology, Medical University of Innsbruck) for confirming the results of a-IgLON5 testing in one of the patient's serum. The authors thank Florian Ingelfinger for his critical reading of the manuscript.

\section{Study Funding}

This work was partially financially supported by the Neuromuscular Center Zurich.

\section{Disclosure}

The authors report no disclosures relevant to the manuscript. Go to Neurology.org/NN for full disclosures.

\section{Publication History}

Received by Neurology: Neuroimmunology \& Neuroinflammation April 19, 2020. Accepted in final form June 2, 2020.

\section{Appendix Authors}

\begin{tabular}{lll}
\hline Name & Location & Contribution \\
\hline $\begin{array}{l}\text { Jana } \\
\text { Werner, MD }\end{array}$ & $\begin{array}{l}\text { University Hospital Zurich, } \\
\text { Department of Neurology }\end{array}$ & $\begin{array}{l}\text { Acquisition of clinical data } \\
\text { and drafting of the } \\
\text { manuscript }\end{array}$ \\
\hline $\begin{array}{l}\text { Ilijas Jelcic, } \\
\text { MD }\end{array}$ & $\begin{array}{l}\text { University Hospital Zurich, } \\
\text { Department of Neurology }\end{array}$ & $\begin{array}{l}\text { Data interpretation and } \\
\text { drafting and revision of the } \\
\text { manuscript }\end{array}$ \\
$\begin{array}{l}\text { Esther Irene } \\
\text { Schwarz, } \\
\text { MD }\end{array}$ & $\begin{array}{l}\text { University Hospital Zurich, } \\
\text { Department of } \\
\text { Pulmonology and Sleep }\end{array}$ & $\begin{array}{l}\text { Data analysis and } \\
\text { interpretation and revision } \\
\text { of the manuscript }\end{array}$ \\
& Disorders Center & \\
\hline
\end{tabular}

Appendix (continued)

\begin{tabular}{|c|c|c|}
\hline Name & Location & Contribution \\
\hline $\begin{array}{l}\text { Elisabeth } \\
\text { Probst- } \\
\text { Müller, MD, } \\
\text { PhD }\end{array}$ & $\begin{array}{l}\text { University Hospital Zurich, } \\
\text { Department of } \\
\text { Immunology }\end{array}$ & $\begin{array}{l}\text { Serologic study, data } \\
\text { analysis and } \\
\text { interpretation, and } \\
\text { revision of the manuscript }\end{array}$ \\
\hline $\begin{array}{l}\text { Jakob } \\
\text { Nilsson, } \\
\text { MD, PhD }\end{array}$ & $\begin{array}{l}\text { University Hospital Zurich, } \\
\text { Department of } \\
\text { Immunology }\end{array}$ & $\begin{array}{l}\text { HLA typing, data analysis } \\
\text { and interpretation, and } \\
\text { revision of the manuscript }\end{array}$ \\
\hline $\begin{array}{l}\text { Bernhard } \\
\text { Schwizer, } \\
\text { MD }\end{array}$ & Lindenhofspital, Bern & $\begin{array}{l}\text { Critical revision of the } \\
\text { manuscript for intellectual } \\
\text { content }\end{array}$ \\
\hline $\begin{array}{l}\text { Konrad } \\
\text { Ernst Bloch, } \\
\text { MD }\end{array}$ & $\begin{array}{l}\text { University Hospital Zurich, } \\
\text { Department of } \\
\text { Pulmonology and Sleep } \\
\text { Disorders Center }\end{array}$ & $\begin{array}{l}\text { Critical revision of the } \\
\text { manuscript for intellectual } \\
\text { content }\end{array}$ \\
\hline $\begin{array}{l}\text { Andreas } \\
\text { Lutterotti, } \\
\text { MD }\end{array}$ & $\begin{array}{l}\text { University Hospital Zurich, } \\
\text { Department of Neurology }\end{array}$ & $\begin{array}{l}\text { Critical revision of the } \\
\text { manuscript for intellectual } \\
\text { content }\end{array}$ \\
\hline $\begin{array}{l}\text { Hans- } \\
\text { Heinrich } \\
\text { Jung, MD }\end{array}$ & $\begin{array}{l}\text { University Hospital Zurich, } \\
\text { Department of Neurology }\end{array}$ & $\begin{array}{l}\text { Critical revision of the } \\
\text { manuscript for intellectual } \\
\text { content }\end{array}$ \\
\hline $\begin{array}{l}\text { Bettina } \\
\text { Schreiner, } \\
\text { MD }\end{array}$ & $\begin{array}{l}\text { University Hospital Zurich, } \\
\text { Department of Neurology } \\
\text { and University Zurich } \\
\text { Institute of Experimental } \\
\text { Immunology }\end{array}$ & $\begin{array}{l}\text { Conception and design of } \\
\text { study, data analysis and } \\
\text { interpretation, and } \\
\text { drafting and revision of the } \\
\text { manuscript }\end{array}$ \\
\hline
\end{tabular}

\section{References}

1. Sabater L, Gaig C, Gelpi E, et al. A novel non-rapid-eye movement and rapid-eye-movement parasomnia with sleep breathing disorder associated with antibodies to IgLON5: a case series, characterisation of the antigen, and post-mortem study. Lancet Neurol 2014;13:575-586.

2. Gaig C, Graus F, Compta Y, et al. Clinical manifestations of the anti-IgLON5 disease. Neurology 2017;88:1736-1743.

3. Nissen MS, Blaabjerg M. Anti-IgLON5 disease: a case with 11-year clinical course and review of the literature. Front Neurol 2019;10:1056.

4. Gelpi E, Höftberger R, Graus F, et al. Neuropathological criteria of anti-IgLON5related tauopathy. Acta Neuropathol 2016;132:531-543.

5. Sabater L, Planagumà J, Dalmau J, Graus F. Cellular investigations with human antibodies associated with the anti-IgLON5 syndrome. J Neuroinflammation 2016;13:226.

6. Schröder JB, Melzer N, Ruck T, et al. Isolated dysphagia as initial sign of anti-IgLON5 syndrome. Neurol Neuroimmunol Neuroinflamm 2017;4:e302.

7. Tao QQ, Wei Q, Song SJ, Yin XZ. Motor neuron disease-like phenotype associated with anti-IgLON5 disease. CNS Neurosci Ther 2018;24:1305-1308.

8. Honorat JA, Komorowski L, Josephs KA, et al. IgLON5 antibody: neurological accompaniments and outcomes in 20 patients. Neurol Neuroimmunol Neuroinflamm 2017;4:e385.

9. Wenninger S. Expanding the clinical spectrum of IgLON5-syndrome. J Neuromuscul Dis 2017;4:337-339.

10. de Carvalho M, Dengler R, Eisen A, et al. Electrodiagnostic criteria for diagnosis of ALS. Clin Neurophysiol 2008;119:497-503.

11. Hasselbacher K, Steffen A, Wandinger KP, Brüggemann N. IgLON5 antibodies are infrequent in patients with isolated sleep apnea. Eur J Neurol 2018;25:e46-e47.

12. Mangesius S, Sprenger F, Höftberger R, Seppi K, Reindl M, Poewe W. IgLON5 autoimmunity tested negative in patients with progressive supranuclear palsy and corticobasal syndrome. Parkinsonism Relat Disord 2017;38:102-103. 


\title{
Neurology \\ Neuroimmunology \& Neuroinflammation
}

\author{
Anti-IgLON5 Disease: A New Bulbar-Onset Motor Neuron Mimic Syndrome \\ Jana Werner, Ilijas Jelcic, Esther Irene Schwarz, et al. \\ Neurol Neuroimmunol Neuroinflamm 2021;8; \\ DOI 10.1212/NXI.0000000000000962
}

This information is current as of February 2, 2021

Updated Information \&

Services

References

Permissions \& Licensing

Reprints including high resolution figures, can be found at:

http://nn.neurology.org/content/8/2/e962.full.html

This article cites 12 articles, 2 of which you can access for free at: http://nn.neurology.org/content/8/2/e962.full.html\#\#ref-list-1

Information about reproducing this article in parts (figures,tables) or in its entirety can be found online at:

http://nn.neurology.org/misc/about.xhtml\#permissions

Information about ordering reprints can be found online: http://nn.neurology.org/misc/addir.xhtml\#reprintsus

Neurol Neuroimmunol Neuroinflamm is an official journal of the American Academy of Neurology.

Published since April 2014, it is an open-access, online-only, continuous publication journal. Copyright

Copyright (C) 2021 The Author(s). Published by Wolters Kluwer Health, Inc. on behalf of the American

Academy of Neurology.. All rights reserved. Online ISSN: 2332-7812.

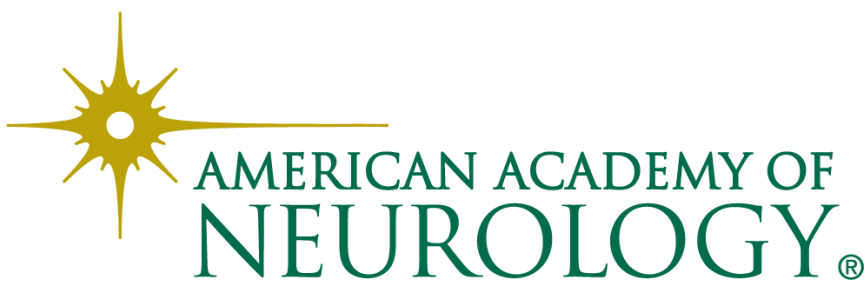

